УДК 663.1, 663.5

\title{
ENERGY POTENTIALS \\ OF THE GAZ-LIQUID MEDIA
}

\author{
A. Sokolenko, O. Shevchenko, O. Bilyk, S. Myronenko \\ National University of Food Technologies
}

\begin{tabular}{l} 
Key words: \\
Gas-liquid medium \\
Alcohol \\
Carbon dioxide \\
Energy potential \\
Solubility \\
Circulating circuit \\
\hline
\end{tabular}

Article history:

Received 09.01.2018

Received in revised form

23.01.2018

Accepted 07.02.2018

Corresponding author:

O. Shevchenko

E-mail:

npnuht@ukr.net

\begin{abstract}
The article concerns to the estimation of energy potentials of gas-liquid media. Such potentials are represented by the aggregate of the chemical energy of dissolved sugars in the conditions of anaerobic fermentation processes, which are culminated with the formation of ethyl alcohol and carbon dioxide with the release of free energy in $230 \mathrm{~kJ} / \mathrm{mole}$ of fermented glucose. From the last $169 \mathrm{~kJ}$ it is transformed into heat energy, which should be removed from the culture medium, and $61 \mathrm{~kJ}$ is used by yeast cells. The self-propelled formation of dissolved carbon dioxide with the subsequent synthesis of the dispersed gas phase leads to the initiation of the circulating circuits of the gas-liquid mixture amplified by the effects of thermal circulation circuits. The presence and continuous renewal of the dispersed gas phase indicates the presence of the potential for the formation of the phasesurface, and the presence of the gas-retaining ability of the system means a certain level of potential energy of a swollen gas-liquid medium.

For anaerobic fermentation, the gas-holding ability is determined by a combination of two sources, namely the forced introduction the dispersed mass of air into the medium and synthesized carbon dioxide in a medium. Thus, internal microbiological transformations lead to the formation of flows of thermal energy, material flows of $\mathrm{C}_{2} \mathrm{~N}_{5} \mathrm{OH}$ and $\mathrm{CO}_{2}$, the kinetic energy of circulating circuits, the potential energy of dissolved carbon dioxide and swollen media. In addition, under the influence of hydrostatic pressure, a gradient of saturation level of the liquid phase on $\mathrm{CO}_{2}$ is formed, which completes by the additional driving factor of the circulating circuits.

The physical basis of the potentials of dissolved gases in the form of manifestations of the presence of a gravitational field and Henry's law is shown, mathematical formalizations are proposed in the estimations of the energy potentials of soluble gases and the possibilities of intensification of mass transfer processes due to their release in ripple regimes.
\end{abstract}

DOI: $10.24263 / 2225-2924-2018-24-1-15$ 


\title{
ЕНЕРГЕТИЧНІ ПОТЕНЦІАЛИ \\ ГАЗОРІДИННИХ СЕРЕДОВИЩ
}

\author{
А.І. Соколенко, О.Ю. Шевченко, О.А. Білик, С.М. Мироненко \\ Національний університет харчових технологій
}

У статті оиінено енергетичні потенціали газорідинних середовищ, представлені сукупністю хімічної енергії розчинених иукрів в умовах процесів анаеробного бродіння, які завершуються утворенням етилового спирту $i$ діоксиду вуглецю з виділенням вільної енергії в 230 кДж/моль зброджуваної глюкози. 3 останньої 169 кДж трансформується в теплову енергію, яка має відводитись із культурального середовища, а 61 кДж використовується дріжджовими клітинами. Самоплинне утворення розчиненого діоксиду вуглеию з поддальшим синтезом диспергованої газової фази призводить до започаткування ииркуляційних контурів газорідинної суміші, підсилених впливами теплових циркуляційних контурів. Наявність $i$ безперервне оновлення диспергованої газової фази вказує на наявність потенціалу утворення міжфазної поверхні, а наявність газоутримувальної здатності системи означає певний рівень потенціальної енергії набухлого газорідинного середовища.

За аеробного бродіння газоутримувальна здатність визначається сукупністю двох джерел, а саме: за рахунок примусового введення в середовище диспергованої маси повітря та синтезованого в середовищі діоксиду вуглецю. Таким чином, внутрішні мікробіологічні перетворення призводять до утворення потоків теплової енергії, матеріальних потоків $\mathrm{C}_{2} \mathrm{H}_{5} \mathrm{OH}$ та $\mathrm{CO}_{2}$, кінетичної енергії ичркуляційних контурів, потенціальної енергї розчиненого діоксиду вуглещю $і$ набухлого середовища. Окрім того, під впливом гідростатичного тиску утворюється градієнт по рівню насичення рідинної фази на $\mathrm{CO}_{2}$, який завершується додатковим рушійним фактором ичркуляційних контурів.

Показано фізичне підтрунтя потенціалів розчинених газів у формі проявів присутності гравітаційного поля $i$ закону Генрі. Запропоновано математичні формалізації в оцінках енергетичних потенціалів розчинених газів і можливості інтенсифікачї масообмінних процесів за рахунок їх вивільнення в пульсачійних режимах.

Ключові слова: газорідинне середовище, спирт, діоксид вуглечю, енергетичний потенціал, розчинність, цииркуляційний контур.

Постановка проблеми. Процеси анаеробного і аеробного бродіння відбуваються в середовищах, у яких наявна диспергована газова фаза. Порушення умови суцільності культуральних середовищ в анаеробних умовах досягається за рахунок самоплинних процесів синтезу діоксиду вуглецю, тоді як за аеробних процесів синтезований $\mathrm{CO}_{2}$ доповнюється введенням у середовище повітряної фази для розчинення в ньому кисню.

Енергетичний потенціал від початку процесів представлений хімічною енергією розчинених цукрів [1-3], однак подальший перебіг бродіння супро- 
воджується утворенням потенціальної енергії набухлого шару, зростаючого тиску і появою циркуляційних контурів. Такі перетворення, без сумніву, відповідають природним закономірностям, однак у наведених прикладах вони не відображені, виключаючи процеси синтезу етилового спирту й діоксиду вуглецю [4-6]. Важливо, що перебіг процесів бродильних технологій значною мірою залежить від геометричних параметрів апаратів і культуральних середовищ, однак і ці взаємозв'язки в дослідженнях практично не представлені.

Метою дослідження $\epsilon$ аналіз фізичного підгрунтя при оцінці енергетичних потенціалів газонасичених анаеробних середовищ і розробка їх математичних формалізацій.

Методи досліджень використані на рівні узагальнень законів природи в прикладних вирішеннях задач удосконалення технологічних процесів.

Викладення основних результатів дослідження. Термін «газорідинне середовище» стосується систем, у яких наявні газова і рідинна фази. При цьому газова фаза є динамічною і такою, яка під дією гравітаційного поля i архімедових сил утворює висхідні потоки відносно рідинної фази, що одночасно є причиною створення вертикально спрямованих циркуляційних контурів. У більшості випадків газова фаза є диспергованою і їі утворення пов'язане 3 анаеробним бродінням, при якому вона генерується внаслідок біохімічних процесів. Енергетичне підгрунтя такого синтезу представлене хімічною енергією речовин живлення мікроорганізмів, трансформація якої супроводжується біохімічними перетвореннями, синтезом цільових речовин $\mathrm{i}$ діоксиду вуглецю. Оскільки середовища біохімічного синтезу характеризуються значною однорідністю живильних компонентів і мікроорганізмівспоживачів останніх, то система вважається такою, в якій диспергована газова фаза також наближається до рівня рівномірно розосередженої. Однак від початку формування однорідність іiі перебування в рідинній фазі порушується з утворенням циркуляційних контурів.

Аналогічні перетворення мають місце в технологіях зброджування виноградного сусла у виноробній промисловості (первинне виноробство), в технологіях вторинного бродіння у виробництві шампанського, при зброджуванні пивного сусла або цукровмістких середовищ у спиртовій промисловості тощо.

Хоча вхідні сировинні потоки названих технологій мають певні відмінності, однак їх спільною характеристикою $є$ те, що всі вони носії хімічної енергії цукрів. Названа спільність продовжується ланцюгом перетворень, які збігаються (рис. 1).

Вхідні матеріальні потоки представлені рідинним середовищем-розчинником, цукрами як живильними компонентами і мікроорганізмами, а хімічна енергія живильних речовин $є$ основою подальших перетворень.

Загальну оцінку взаємодії вхідних потоків і біохімічного синтезу виконано 3 урахуванням перебігу процесів, починаючи від відомого рівняння ГейЛюссака, схеми спиртового бродіння за Ембденом-Мейєргофом-Парнасом [1] i форм бродінь, відкритих К. Нейбергом [2]. Першою формою бродіння $\epsilon$ нормальне спиртове бродіння 3 одержанням $\mathrm{C}_{2} \mathrm{H}_{5} \mathrm{OH}$ і $\mathrm{CO}_{2}$. Друга форма це бродіння за наявності бісульфіту для отримання гліцерину, а третій формі відповідає бродіння за наявності бікарбонату натрію. Проте на відміну від 
цих процесів термодинамічні та фізичні наслідки синтезу діоксиду вуглецю представлені помітно обмежено [3; 4].

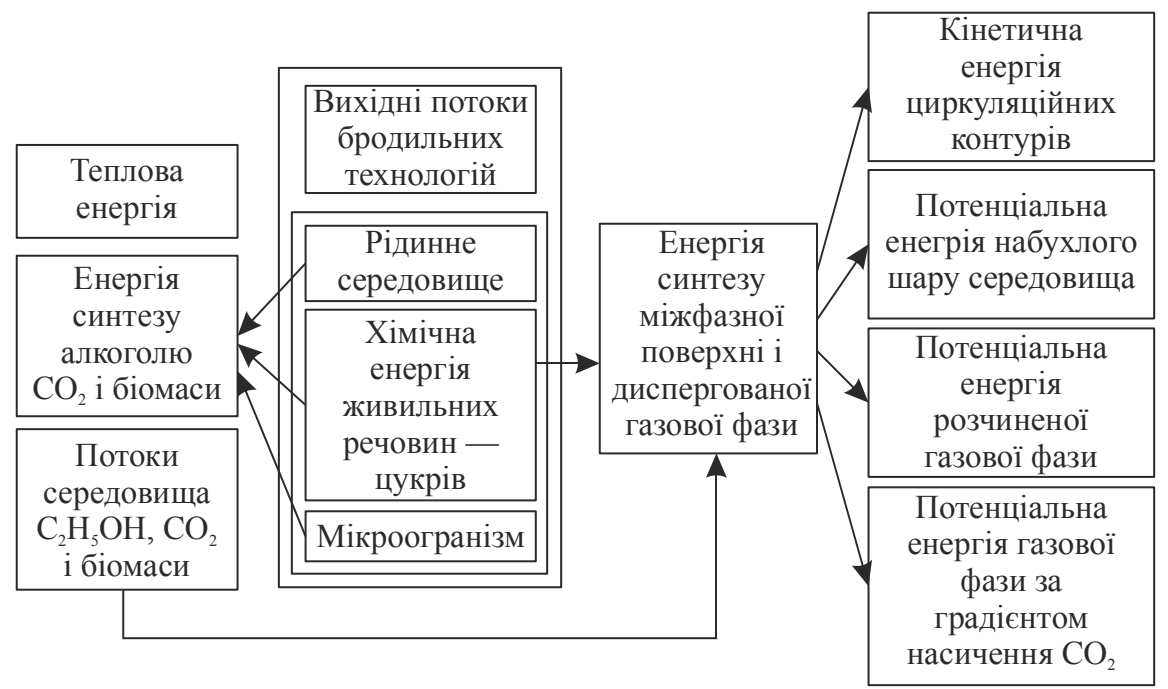

Рис. 1. Схема трансформацій матеріальних і енергетичних потоків

Очевидно, що за умови анаеробного бродіння газова фаза представлена діоксидом вуглецю, динаміка синтезу якого пов'язана з організацією технологічного процесу, що є цілком визначеним, і при цьому в режимах перехідних процесів виникає повисотна нерівномірність вмісту розчиненого $\mathrm{CO}_{2}$ завдяки гідростатичному тиску.

Аеробні процеси частіше пов'язані 3 прискореним синтезом біомаси i супроводжуються технічними заходами для подавання в рідинну фазу кисню, оскільки дріжджі здатні асимілювати лише його розчинену форму.

Аерація середовищ здійснюється подаванням і диспергуванням в них повітря. Оскільки режими аерації регламентуються концентраціями розчиненого кисню, споживач якого наявний у середовищі, то за таких умов неминуче досягається повне насичення його азотом.

Однак при цьому азот як складова повітря не просто проходить «транзитом» рідинну фазу, а у значній кількості на поверхні поділу фаз відбуваються масообмінні процеси по кисню, діоксиду вуглецю і азоту. Якщо при цьому спрямованість потоку кисню цілком визначена в напрямку від газової фази до рідинної, то потоки азоту на поверхні поділу фаз можуть бути різнонаправленими. Такими різнонаправленими можуть бути і потоки $\mathrm{CO}_{2}$.

Спряженість названих трьох потоків на поверхнях поділу фаз впливає на інтенсивність масообмінних процесів, однак рушійні фактори при цьому в першому наближенні будемо визначати на основі закону Генрі.

Очевидно, що рівень складності масообмінних процесів на поверхнях мікробіологічних клітин суттєво більший, однак 3 урахуванням того, що питома поверхня цього масообміну переважає міжфазну поверхню не менше як на три порядки, ця частина винесена за межі цього дослідження. 
Проте існують можливості впливу на середовища з метою інтенсифікації масообмінних процесів за рахунок використання енергетичних потенціалів, названих у схемі (рис. 1). Оцінка можливостей їх реалізації пов'язана 3 цим дослідженням.

Фізичне підтрунтя в оціниі потениіалів розчинених газів. Практично невикористаним людством залишається потенціал, який є результатом взаємодії гравітаційного поля й атмосфери Землі. Наслідком такої взаємодії є розчинене в гідросфері повітря, що регламентується законами природи, які визначають впливи на розчинність складових атмосфери.

Відомо, що розчинність газів визначається законом Генрі, за яким стала насичення пропорційна парціальному тиску $P$ газу на поверхні поділу фаз [5]:

$$
c_{\mathrm{H}}=k_{\mathrm{\Gamma}} P,
$$

де $k_{2}$ - константа Генрі, числове значення якої залежить від фізико-хімічних властивостей рідинної та газової фаз і температури рідинного середовища.

Вказівкою на існування потужного потенціалу розчинених у гідросфері газів $\epsilon$ відоме явище, пов'язане 3 порушенням стану механічної й термодинамічної рівноваги на поверхні поділу фаз у зв'язку з проходженням великих морських суден. Взаємодія корпусів суден, режими їх обтікання водою i, особливо, взаємодія 3 рушійними гвинтами супроводжується утворенням масивів бульбашок з розчиненої газової фази і частково з атмосфери (рис. 2). Зона 3 порушеною умовою термодинамічної рівноваги супроводжує трасу переміщення судна, а газова фаза, яка поповнюється за рахунок циркуляційних потоків і підведення глибинних газонасичених шарів води, може існувати до кількох діб. Зародження та існування циркуляційних контурів пов'язане 3 локальним порушенням однорідності поля гідростатичних тисків, а їх енергетична підтримка забезпечується утворенням диспергованої газової фази.



Рис. 2. Схема доутворення циркуляційних контурів у газонасиченій гідросфері

Механізм насичення глибинних шарів води має двостадійність. На першому етапі - це розчинення повітря на границі поділу фаз, на другому дифузія за рахунок градієнта сталої насичення $c_{H}$, яка зростає зі збільшенням глибини $h$. Наявність розчиненого повітря в гідросфері Землі є загальновизнаною, однак інформація щодо рівнів насичення глибин гідросфери 
відчутно обмежена. У зв'язку з існуванням підводного рослинного світу і гідробіонтів та процесів окислення органічних речовин, очевидно, що за показником насичення має переважати азот. Однак $з$ точки зору інтересів оцінки енергетичного потенціалу це має обмежений вплив на систему.

Енергетичний потенціал розчинених у рідинних середовищах газів визначається їх концентрацією і тиском у системі, який однак не має фізичних проявів за умови термодинамічної рівноваги. Останнє положення слід розглядати як певну модифікацію системи, що відображується рівнянням Менделєєва-Клайперона, оскільки його ліва частина у формі PV стосується об'єму $V$ суто газової фази. Однак параметри правої частини MRT відповідають реальному газу, а в сукупності - його енергетичному потенціалу. Підставою для такого гіпотетичного висновоку $є$ те, що прояв енергетичного потенціалу розчиненого газу має місце тільки за умови його десорбції і в результаті суто механічної взаємодії з рідинною фазою. При цьому маса газу в такій енергетичній трансформації залишається рівною або кратною $M$, а газова стала $R$ і температура $T$ відповідають саме газовій фазі. Посилання на кратність маси М пов'язане з тим, що не весь розчинений газ у режимі десорбції завжди переходить у газову фазу. Таким чином, енергія десорбційного виділення розчиненої газової фази дорівнює:

$$
E=M R T \text {, }
$$

а масу утвореної газової фази знайдемо за умовою:

$$
M=k_{\text {г }}\left(P_{\text {(п) }}-P_{(\kappa)}\right) V_{\mathrm{p}},
$$

де $k_{\text {г }}$ - константа Генрі; $P_{(\text {п) }}$ і $P_{(\text {к) }}-$ початковий і кінцевий парціальні тиски або фізичні тиски в системі; $V_{\mathrm{p}}$ - об'єм рідинної фази, з якої виділяється розчинений газ.

Очевидно, що створення енергетичних накопичувальних пристроїв потребує врахування параметрів розчинності. Впливи температур на розчинність газів відображено в таблиці [6].

Таблиця. Розчинність газів у воді $\mathbf{m}^{3} / \mathrm{m}^{3}$ за парціального тиску 0,1 МПа

\begin{tabular}{|c|c|c|c|c|c|c|c|c|}
\hline \multirow{2}{*}{ Газ } & \multicolumn{7}{|c|}{ Температура, ${ }^{\circ} \mathrm{C}$} \\
\cline { 2 - 9 } & 0 & 5 & 10 & 15 & 20 & 25 & 30 & 40 \\
\hline Азот & 0,0235 & 0,0209 & 0,0186 & 0,0168 & 0,0154 & 0,0143 & 0,0134 & 0,0118 \\
Кисень & 0,0489 & 0,0425 & 0,0380 & 0,0341 & 0,0310 & 0,0283 & 0,0264 & 0,0231 \\
Водень & 0,0215 & 0,0204 & 0,0195 & 0,0198 & 0,0182 & 0,0175 & 0,0170 & 0,0164 \\
Діоксид & & & & & & & & \\
вуглецю & 1,713 & 1,425 & 1,194 & 1,019 & 0,878 & 0,759 & 0,665 & 0,530 \\
\hline
\end{tabular}

Зіставлення даних, наведених у таблиці, показує суттєву перевагу за значенням розчинності діоксиду вуглецю. Вказану перевагу більш логічно застосувати в бродильних технологіях або в спеціальних технологіях за рахунок примусового насичення рідинної фази діоксидом вуглецю. Так, за десатурації 10 кг $\mathrm{CO}_{2} 31 \mathrm{~m}^{3}$ середовища енергетичний потенціал переходу складе:

$$
E=10 \cdot 188,9(273+12)=538365 \text { Дж. }
$$


Якщо процес десатурації складе у часі 10 с, то потужність енергетичної трансформації оцінюється у середньому обчисленні величиною:

$$
N=\frac{E}{a}=\frac{538,4}{10}=53,84 \text { кВт. }
$$

Одержане значення потужності $N$ приблизно на порядок перевищує імпульси енергетичних впливів у класичних технологіях. Створення на основі розчинених газів енергетичних накопичувачів можливе за штучного одержання різних рівнів термодинамічної рівноваги. Важливо, що закон Генрі дає вказівку на їх досягнення в кількісних співвідношеннях. Підвищення тиску $\mathrm{CO}_{2}$ в системі із сировиною підвищеної вологості означає зростаючий рівень насичення рідинної фракції і зростаючий енергетичний потенціал. Досліди, які стосувалися ягід винограду, бурякової стружки, подрібнених фруктів тощо привели до однозначного висновку про ефективність швидкоплинного скидання тиску з руйнуванням структур твердої фази на міжклітинному і клітинному рівнях [7-10].

Очікування високого руйнівного рівня десорбції $\mathrm{CO}_{2} 3$ вологої фракції середовищ пов'язується з глибоким проникненням газу у складові середовища, у тому числі і на клітинному рівні.

Фізичне підгрунтя технологій різкого зниження тисків (ТРЗТ) відрізняється від фізичних основ дискретно-імпульсних технологій, хоча за структурною побудовою в отриманні енергетичних впливів вони подібні. В обох випадках передбачається накопичення енергетичного потенціалу з подальшим різким переведенням системи в метастабільний стан і до нового стану термодинамічної рівноваги. Аналіз енергетичних потенціалів порівнюваних систем приводить до висновку про їх еквівалентність і наближення потужностей, що реалізуються в НВЧ технологіях.

Відмінністю ТРЗТ-методів, порівняно з дискретно-імпульсними технологіями, $\epsilon$ те, що підвищення їх енергетичних потенціалів супроводжуються різними напрямками зміни температур, оскільки розчинність газів зростає зі зниженням температури, а в ДІТ технологіях збільшенню потенціалів середовищ відповідає зростання температур.

При цьому на увагу в обох випадках заслуговує швидкоплинність зниження енергетичних потенціалів, яка може значно підсилюватися вакуумуванням середовищ. Залежно від рівня входження середовища в незрівноважений стан за показником температури швидкість ії зниження може досягати $10 \ldots 15^{\circ} \mathrm{C}$ за секунду і більше на початку процесу з поступовим зменшенням цього показника. Таке швидкісне охолодження досягається за рахунок генерування пари в режимі адіабатного кипіння середовища і стосується всього його об'єму 3 поправкою на гідростатичний тиск. Особливістю режимів адіабатного кипіння $\epsilon$ кавітаційні ефекти, частота появи яких за інших рівних умов залежить від висоти шару рідинної фази, оскільки у зв'язку з гідростатичними тисками верхні шари охолоджуються швидше.

Природа кавітаційних явищ при цьому є традиційною і пов'язаною 3 конденсацією пари в бульбашках. 
Для випадків активної десатурації (дегазації) насичених середовищ можливість кавітаційних ефектів зменшується, оскільки колапс газових бульбашок може пов'язуватися зі збільшенням тиску в системі або зі зменшенням температури, що в умовах ТРЗТ не досягається.

Сучасне апаратурне оформлення процесів бродіння і технологій мікробіологічного синтезу зорієнтоване на використання герметичних апаратів, які працюють в умовах підвищених тисків або хоча б за існування в них гідростатичних тисків. Так, циліндро-конічні бродильні апарати пивзаводів, акратофори заводів шампанських вин, форфаси пивзаводів, апарати для вирощування мікроорганізмів, для зброджування квасу можуть мати висоту в десятки метрів. Зброджування цукровмістких середовищ означає насичення їх розчиненим діоксидом вуглецю до значень, які відповідають закону Генрі.

При цьому режим насичення має ту особливість, що $\mathrm{CO}_{2}$ передається в рідинну фазу на молекулярному рівні і лише за досягнення значення сталої насичення $c_{н}$ стає можливим утворення газової фази. Однак при цьому наявність гідростатичних тисків визначає нерівномірність концентрації розчиненого діоксиду вуглецю. Відповідний концентраційний градієнт формується від початку виділення $\mathrm{CO}_{2}$ з верхніх шарів середовища, оскільки в більш заглиблених шарах за рахунок гідростатичного тиску насичення поки що не досягається.

Гідродинамічні параметри та інтенсифікащія масообмінних прочесів у газорідинних середовищах. Газорідинні середовища з диспергованою газовою фазою в значній кількості представлені в бродильних технологіях і в технологіях, пов'язаних з синтезом мікробних культур. У першому випадку вони будуються як анаеробні, а у другому - як аеробні. Очевидно, що ці особливості визначають природу газу диспергованої фази. За анаеробної системи це діоксид вуглецю, а за аеробних процесів - це суміш азоту, кисню i діоксиду вуглецю. Хоча фізико-хімічні властивості названих газів різні, однак ix дисперговані у рідинній фазі масиви створюють подібні фізичні поля i подібно реагують на зовнішні збурення систем. Очевидно, що самогенерування газової фази $\mathrm{CO}_{2}$ у середовищі пов'язане з внутрішнім масообміном, а за аеробних процесів диспергована повітряна фаза генерується за рахунок барботажних або інших процесів. В обох випадках інтенсифікація масообміну пов'язана з гідродинамічним станом середовищ і можливостями впливу на них енергоматеріальними імпульсами. У зв'язку з викладеним розглянемо взаємозв'язки між геометричними характеристиками апаратів і середовищ, гідродинамічними параметрами, механічними імпульсними впливами і масообміном.

Прояв енергетичних наслідків зброджування середовищ відбувається у певній послідовності.

По-перше, в результаті життєдіяльності мікроорганізмів досягається накопичення в рідинній фазі спирту та діоксиду вуглецю з поступовим наближенням до стану насичення. При цьому час настання такого насичення на $\mathrm{CO}_{2}$ в перехідному процесі та його числовий показник залежать від величини гідростатичного тиску. У зв'язку з цим зона утворення газової фази у формі бульбашок починається з поверхні рідинної фази і поступово розширюється у бік заглиблення в середовище. 
За відомої і програмованої швидкості зброджування середовища можливим є визначення швидкості синтезу $\mathrm{CO}_{2} d c_{\text {н }} / d \tau$, кг $/\left(\mathrm{м}^{3} \cdot \mathrm{c}\right)$. Тоді за умови стабільної кількості мікроорганізмів та інших параметрів бродіння записуємо для елементарного шару товщиною $\mathrm{dx}$ на висоті х (рис. 3) умову:

$$
\left(\frac{d c_{\mathrm{H}}}{d \tau}\right) \tau_{(x)}=k_{\mathrm{r}}\left(P_{o}+\rho g x\right), \kappa \Gamma / \mathrm{M}^{3},
$$

де $\tau_{(x)}-$ час досягнення повного насичення шару на висоті $x ; P_{o}-$ зовнішній тиск; $\rho$ - питома маса рідинної фази.



Рис. 3. Схема довизначення параметрів квазіпружної газорідинної системи

Звідси знайдемо:

$$
\tau_{(x)}=k_{\mathrm{\Gamma}} \frac{P_{o}+\rho g x}{d c_{\mathrm{H}} / d \tau}, \mathrm{c},
$$

а час, за якого почнеться генерування газової фази $\mathrm{CO}_{2}$ у повному об'ємі середовища, визначається за $x=H$. Тоді

$$
\tau_{(x)}=k_{\mathrm{r}} \frac{P_{o}+\rho g H}{d c_{\mathrm{H}} / d \tau} .
$$

По-друге, від моменту початку синтезу диспергованої газової фази розпочинається етап прояву потенціальної енергії набухлого шару газорідинної суміші. Це означає, що середовище вміщує в собі певний об'єм газової фази, що відповідає відомому поняттю газоутримувальної здатності. Останню в експериментальних вимірах визначають різницею $\Delta \mathrm{H}$ рівнів набухлого $H_{\text {наб. }}$ і ненабухлого $H_{\text {н.н. }}$ середовища:

$$
u=F_{\text {ап }}\left(H_{\text {наб. }}-H_{\text {н.н. }}\right), \mathrm{M}^{3},
$$

де $F_{\text {ап }}$ - площа поперечного перерізу апарата, м² 
Утримувальна здатність середовища є важливою гідродинамічною характеристикою, пов'язаною 3 такими параметрами, як поверхня поділу фаз i приведена швидкість диспергованої газової фази $w_{\text {пр }}$.

Ефект утворення набухлого шару свідчить, що певна частина газорідинної суміші здійснила переміщення у гравітаційному полі проти сил тяжіння. Це означає, що виконана певна робота, величина якої дорівнює потенціальній

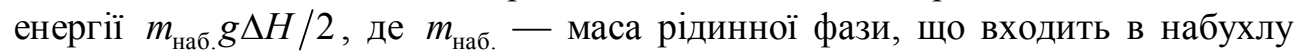
частину шару. 3 певним наближенням будемо вважати, що об'єм рідинної фази на ділянці $\Delta H$ рівний утримувальній здатності. Це припущення дає змогу вирахувати:

$$
m_{\text {наб. }}=u \rho_{\text {рід. }}, \kappa \Gamma,
$$

де $\rho_{\text {рід. }}$ - питома маса рідинної фази.

Якщо вважати, що розподіл рідинної фази в набухлій частині є ізотропним, то потенціальна енергія набухлої частини системи дорівнює:

$$
E_{\text {наб. }}=m_{\text {наб. }} g \frac{\Delta H}{2}=u \rho_{\text {рід. }} g \frac{\Delta H}{2}, \text { Дж. }
$$

Розчинений $\mathrm{CO}_{2}$ має висотний розподіл, що визначає можливість використання відповідного градієнта як енергетичного потенціалу. Визначимо загальну кількість діоксиду вуглецю, що перебуває в розчиненому стані. Елементарна по висоті $d x$ ділянка на рівні $x$ (рис. 3) вміщує у собі $\mathrm{CO}_{2}$ в кількості:

$$
d M_{\mathrm{CO}_{2}}=c_{\mathrm{H}} d V=c_{\mathrm{H}} F_{\text {ап. }} d x, \kappa \Gamma .
$$

У результаті підстановки $c_{н}$ одержуємо:

$$
d M_{\mathrm{CO}_{2}}=k_{2}(P+\rho g x) F_{\text {ап. }} d x, \kappa \Gamma,
$$

а інтегрування цього виразу дає змогу визначити кількість $\mathrm{CO}_{2}$ для всього середовища:

$$
\begin{gathered}
M_{\mathrm{CO}_{2}}=\int_{0}^{H} k_{\text {г }}(P+\rho g x) F_{\text {ап. }} d x=k_{\text {г }} P F_{\text {ап. }} \int_{0}^{H} d x+k_{\text {г }} \rho g F_{\text {ап. }} \int_{0}^{H} x d x= \\
=k_{\text {г }} P F_{\text {ап. }} H+k_{\text {г }} \rho g F_{\text {ап. }} \frac{H}{2}=k_{\text {г }} F_{\text {ап. }} H(P+0,5 \rho g), \text { кг. }
\end{gathered}
$$

Знайдений енергетичний і відповідний матеріальний потенціали та відповідна їм структура середовища в динамічному стані зберігаються в період усталеної частини процесу бродіння. Очевидно, що зміни швидкості синтезу $\mathrm{CO}_{2}$ мають відобразитися на визначених параметра, а також на геометричних параметрах бродильних апаратів.

По-третє, утворення динамічного газорідинного середовища означає наявність циркуляційних контурів. Природа їх появи пов'язана 3 переміщенням диспергованої газової фази, на що вказують відомі теоретичні та експериментальні визначення абсолютної і відносної швидкостей газової фази. Оскіль- 
ки швидкість спливання газових бульбашок визначається різницею рушійних архімедових сил та сил опору середовища і архімедові сили пропорційні кубу визначального розміру, а сили опору - квадрату останнього, то це вказує на нелінійність залежності швидкості відносного руху від розмірів газової фази. Проте в наших дослідженнях слід відмітити лише те положення, що стосовно середовищ з фіксованими параметрами швидкість газової фази також наближено фіксована. Наприклад, для середовищ із характеристиками близькими до води відносна швидкість бульбашок 3 діаметром 2...6 мм становить $0,25 \ldots 0,27$ м/с. Разом 3 тим в умовах газонасичених середовищ абсолютні швидкості перевищують відносні у 2-3 рази і більше, що відповідає залежності:

$$
w_{\text {абс. }}=w_{\text {від. }}+w_{\text {рід. }},
$$

де $w_{\text {рід. }}$ - середня швидкість винесення газової фази в рідинних циркуляційних контурах.

Наявність висхідних гілок циркуляційних контурів означає наявність опускних і те, що такі контури є замкненими і спрацьовують на підвищення однорідності середовищ. Одночасно вкажемо на зв'язок між утримувальною здатністю середовища по газовій фазі і абсолютною швидкістю, що відображується формулою [10]:

$$
u=\int_{0}^{H_{\text {заг. }}} \frac{M^{\prime} R T}{P+H_{\text {рід. }}-(H-x)} \cdot \frac{d x}{w_{\text {абс. }}}, \mathbf{M}^{3},
$$

де $M^{\prime}$ - масовий синтез $\mathrm{CO}_{2}$, кг/с.

Потенціальна енергія газорідинної системи визначається сукупністю $E_{\text {наб. }}$ та енергії стиснутої газової фази. При цьому в пошуках можливостей силових впливів на газорідинну систему слід звернутися до іiі квазіпружних властивостей $[10 ; 11]$. Розподілена у повному об'ємі диспергована газова фаза виконує роль пружної складової, яка відгукується, наприклад, на зміни тисків. При цьому реакція кожної бульбашки незалежно від ії координат у середовищі $є$ повноцінним відгуком на зміну тиску у формі змін розмірів $\mathrm{i}$ об’єму. Водночас така деформація сукупності бульбашок диспергованої газової фази означає зменшення показника газоутримувальної здатності, що має супроводжуватися зменшенням набухання $\Delta H$. Зниження тиску до номінального повинно завершитися стабілізацією параметрів на попередньому рівні. Очевидно, що за таких умов результат силового впливу залежить від динаміки зміни останнього та його величини і цілком досяжним є значення, яке приведе дисперговану газову фазу до колапсу. Така ситуація має оцінюватися повним аналогом кавітаційних ефектів 3 паровою фазою. Оскільки фізичним підгрунтям колапсу газових бульбашок $\epsilon$ тиск, то з урахуванням градієнта гідростатичного тиску він буде відбуватися у послідовності, починаючи 3 нижніх шарів. Таким чином, для таких газонасичених середовищ 3 диспергованою газовою фазою досягається можливість часткового або повного колапсу з аналогом потужних впливів на рівні кавітаційних.

Якщо силові впливи не досягають значень, за яких відбувається колапс газових бульбашок, то система перетворюється на квазіпружну у формі роз- 
поділеної маси по вертикальній координаті. Разом з тим за наявності даних щодо утримувальної здатності по газовій фазі стає можливою оцінка рівня деформації середовища по висоті. Це означає досягнення оцінки пружних властивостей системи на рівні приведеної жорсткості (рис. 3).

\section{Висновки}

1. Енергетичні потенціали зброджуваних газорідинних середовищ складаються 3 хімічної енергії цукристих речовин, синтезованого етилового спирту, потенціальної енергії розчиненої газової фази, диспергованої газової фази, кінетичної енергії циркуляційних контурів і потенціальної енергії середовища за градієнтом насичення $\mathrm{CO}_{2}$.

2. У сучасному апаратурному оформленні бродильних процесів названі енергетичні потенціали цілеспрямованого використання не знаходять.

3. Енергетичні потенціали зброджуваних анаеробних середовищ створюються на основі розчиненої, а потім диспергованої газової фази в результаті взаємодій гравітаційного поля, законів розчинності Генрі і Архімеда. Співвідношення між силами Архімеда і опору середовищ визначають газоутримувальну здатність останніх. У зв'язку з цим газоутримувальна здатність i енергетичні потенціали збільшуються зі збільшенням висоти ізооб'ємних бродильних апаратів.

\section{Література}

1. Кунце В. Технология солода и пива / В. Кунце, Г. Мит: пер. с нем. - СанктПетербург : Профессия, 2001. - 912 c.

2. Пирог Т.П. Загальна мікробіологія / Т.П. Пирог. - Київ : НУХТ, 2010. - 632 с.

3. Губський Ю.І. Біоорганічна хімія: підруч. / Ю.І. Губський. - 2-е вид., доопрацьоване та доп. - Київ-Вінниця : Нова Книга, 2007. - 432 с.

4. Справочник специалиста пищевых производств. Книга 2. Теплофизические процессы. Энергосбережение / А.И. Соколенко, А.И. Украинец, В.Л. Яровой и др. - Киев : АртЭк, 2003. - $432 \mathrm{c.}$

5. Глинка Н.Л. Общая химия / Н.Л. Глинка. - Ленинград. : Химия, 1984. - 704 с.

6. Тиманюк В.А. Биофизика / В.А. Тиманюк, Е.Н. Животова. - Київ : «Професіонал», 2004. $-704 \mathrm{c}$.

7. Патент 83132 UA, МПК C13D 1/00 (2006.01) Система підготовки стружки до дифузійного процесу / Соколенко А.І., Піддубний В.А., Шевченко О.Ю., Піддубний Ю.А., Котенко М.М., Максименко І.Ф.; заявник Національний університет харчових технологій. № a200611507; заявл. 01.11.2006; опубл. 10.06.2008, Бюл. № 11, 2008 p.

8. Патент 85414 UA, МПК C13D 1/00 (2009.01) Система для одержання дифузійного соку / Соколенко А.І., Піддубний В.А., Шевченко О.Ю., Піддубний Ю.А., Котенко М.М., Максименко І.Ф.; заявник Національний університет харчових технологій. — № a200611504; заявл. 12.05.2008; опубл. 26.01.2009, Бюл. № 2, 2009 р.

9. Патент 97895 UA, МПК C12C 7/00 (2006.01), F04F 5/20 (2006.01) Варильний агрегат для пива / Соколенко А.І., Козодой Ю.А., Піддубний В.А.; заявник Національний університет харчових технологій. - № а201013165; заявл. 05.11.2010; опубл. 26.03.2012, Бюл. № $6,2012 \mathrm{p}$.

10. Підуубний В.А. Наукові основи і апаратурне оформлення перехідних процесів харчових і мікробіологічних виробництв: дис. .... докт. техн. наук: 05.18.12 / Піддуб̆ний Володимир Антонович; НУХТ. - Київ, 2007. — 421 с.

11. Піддубний В.А. Енергетичне підгрунтя тепло- і масообміну в харчових технологіях / В.А. Піддубний // Харчова промисловість. — 2008. — № 6. - С. $80-83$. 